\title{
Position of the pelvis, lower extremities load and the arch of the feet in young adults who are physically active
}

\author{
Agnieszka Jankowicz-Szymańska ${ }^{1}$ Edyta Mikołajczyk², Małgorzata Kołpa ${ }^{1}$ \\ ${ }^{1}$ Institute of Health, State Higher Vocational School, Tarnow, Poland \\ Head of the Institute: Prof. Ryszard Żarów \\ 2 Department of Physiotherapy, University School of Physical Education, Krakow, Poland \\ Head of the Department: Prof. Marek Pieniążek
}

Studia Medyczne 2013; 29 (3): 225-229

Key words: body posture, pelvis position, lower extremities load, feet arching.

\begin{abstract}
Introduction: Body posture is an individual motion habit. It is variable and depends on the gender, age, structure of the body but also on mental and physical state. Although it is difficult to formulate a universal definition of correct body posture, the opinion that its elementary feature is symmetry is beyond any doubt. Such symmetry is related to the position of particular anatomical points and effects of static and dynamic forces.

Aim of the research: To assess the relations between the pelvis position in the frontal plane, the static load on the lower limbs and architecture of the feet. The following features were analysed in a group of young, healthy and particularly physically active women and men: the frequency of asymmetry related to pelvis position, the load on the lower limbs related to body weight and foot architecture.

Material and methods: The study group consisted of 100 students of physical education. To assess the position of the pelvis a palpable-visual method was used. Clarke's method was applied to characterize the foot architecture determined by the position of standing with one leg on the CQElektronik podoscope. The static load on the lower limbs was assessed using the stabilographic platform EMILDUE from Technomex.

Results: Collected data and observations show frequent asymmetric changes of pelvis position in the frontal plane and incorrect balance of the body in the standing position. The change of static load on the lower limbs influences the longitudinal architecture of the feet and this influence is statistically significant. Increased asymmetry of the pelvis in the frontal plane is related to profound disorder of body balance.

Conclusions: Asymmetric position of the pelvis is associated with asymmetric arching of the feet and asymmetric body weight distribution. Full symmetric position of the pelvis is rare even among young people who are physically active.
\end{abstract}

\section{Introduction}

The most fundamental criterion for assessing human body posture in the frontal plane is its symmetry. Undoubtedly, it is extremely rarely good, which - among others - results from the structural asymmetry of internal organs in the body cavity [1]. Even a slight dislocation of bone structures may disturb balanced muscular tension and adversely affect postural stability [2].

The spine, which along with the pelvic girdle and with the help of lower extremities stabilizes the body on the ground, is the key element of human body posture. The quality of posture and gait aesthetics are, to a considerable degree, conditioned by the pelvic biomechanics. The position of the pelvis directly influences the size of spinal physiological curvatures, the shape of the spine in the frontal plane and its rotation, and the axial alignment of lower extremities [3-5]. Pelvic asymmetry may be caused by defensive muscular tension in patients who have pain complaints [6], structural asymmetry of lower extremities, who developed complications after dysplasia of the hip or
Perthes disease, and even in those who have imperfect foot structure and function [7]. The change in the relative length of the lower extremity connected with improper position of the pelvis affects static weight distribution in the standing position, which in turn results in increased pressure on one or the other foot. Asymmetrical position of the pelvis is also influenced by the quality of the sitting position and may contribute to the emergence of pain in the lower part of the spine [8].

\section{Aim of the research}

The study focused on determining the incidence of pelvic asymmetry in the frontal plane, and on assessing distribution of static weight bearing on lower extremities and the longitudinal arch of the foot of young, physically active adults. Dependencies between the variables under research were also sought.

\section{Material and methods}

A total of 100 students of PE at the State Vocational School in Tarnów, Poland, including 50 males and 
50 females, constituted the research group. All the participants boasted a good general state of health and none of them were treated for chronic diseases, had pain complaints or felt bad on the day of the survey. Those students who had been diagnosed with scoliosis exceeding $10^{\circ}$ curvature, varus or valgus knees, and those who had suffered from injuries to the locomotor organs within the past 6 months before the survey were excluded from the measurements. Basic characteristics of somatic structure (body mass and height) and selected elements of body posture were evaluated. The symmetrical/asymmetrical position of the anterior superior iliac spine (ASIS) and the posterior superior iliac spine (PSIS), the body weight bearing distribution on feet and the longitudinal arch of the right and left foot were registered on the survey chart. A calibrated anthropometer, the Tanita scales, the stabilometric platform EMILDUE and a CQ Elektronik podoscope with relevant software were employed as the research tools.

The symmetry of the position of the ASIS and the PSIS was evaluated by means of visual inspection and palpation. Once the positions of iliac spines were marked on the participant's skin, they were noted accordingly on the survey chart as symmetric iliac spines, or an elevated right or an elevated left iliac spine.

The distribution of static weight bearing on lower extremities was assessed by means of a computerised stabilometric platform. The participant assumed a natural standing position with both their feet planted firmly on the platform and maintained it for $30 \mathrm{~s}$. After that time the average body weight bearing on the right and left foot appeared on the monitor as the percentage value.

The longitudinal arch of the foot was measured in Clarke's angles, and calculated using digital plantar images of the foot registered in one-foot standing on the electronic podoscope. It was assumed that angular values between $42^{\circ}$ and $54^{\circ}$ corresponded to a proper arch, and those between $31^{\circ}$ and $41^{\circ}$ to a lowered one, while $30^{\circ}$ corresponded to a flat foot and $55^{\circ}$ or more to a hollow foot [9].

\section{Statistical analysis}

The analysis of the data was made employing basic numerical statistics, an $F$-test for testing the equality of two variances and a $t$-test for testing two equal variances. Dependencies between variables were determined by means of Spearman's rank correlation and Pearson's linear correlation. The most frequently used level of gravity was accepted and it was assumed that correlations were significant if $p<0.05$.

\section{Results}

A total of $92 \%$ of female participants had proper body mass index (BMI) values, while overweight and underweight were found in $4 \%$ of them. A total of $88 \%$ of male participants boasted proper BMI; the remaining males (12\%) had excessive body weight.

Symmetric position of the pelvis was observed in $58 \%$ of females (29 participants) and in $52 \%$ of males (26 participants). An elevated position of the left ASIS, as compared to the right one, was discovered in $18 \mathrm{fe}-$ males (36\%) and in 19 males (39\%). Three female and 5 male participants had an elevated position of the right anterior iliac spine. Similar observations were made in the case of posterior iliac spines. The left posterior iliac spine was elevated in comparison with the right one in 27 per 100 participants, while an elevated right posterior iliac spine occurred in 8 participants. It should be noted that an elevated position of the left iliac spine, as compared to the right one, occurred more frequently in both genders.

Only in $16 \%$ of females (8 participants) and in $32 \%$ of males (16 participants) was body weight bearing distributed symmetrically in both legs, while they maintained their habitual standing positions. Most participants, i.e. $64 \%$ of females (32 participants) and $50 \%$ of males (25 participants), support their weight on the left leg. Increased weight bearing of the right foot was noted in $20 \%$ of females (10 participants) and in $18 \%$ of males ( 9 participants).

Proper foot arch was characteristic of $78 \%$ of males (39 participants) and 76\% of females (38 participants). The relevant values for the left foot equalled $66 \%$ (33 males) and 62\% (31 females). A lowered arch of the right foot was discovered in $22 \%$ of females and males (in 11 participants in each gender), while a lowered arch of the left foot was found in 30\% of males (15 participants) and in 36\% of females (18 participants). One of the females had her right foot flat (2\%), and 2 males (4\%) and 1 female (2\%) had their left foot flat. No participants with excessively raised arch of the foot were discovered.

The correlation analysis showed significant dependency between the position of the ASIS and the PSIS in the frontal plane and static lower extremity weight bearing (Table 1). Significant, but smaller dependencies were also found between the position of anterior and posterior iliac spines and the longitudinal arch of the foot (Table 2). Pearsons linear correlation showed a significant dependency between static weight bearing of the left and right leg in a habitual standing position and the longitudinal arch of the foot (Table 3).

\section{Discussion}

The vast majority of participants had good proportions of their body weight to their body height. All of them were young and healthy, and boasted more than average physical fitness, due to their interests and field of study, but despite that the occurrence of asymmetry was observed in them. 
Table 1. The relationships between the pelvis and the load setting of the lower limbs

\begin{tabular}{|lccc|}
\hline Variables & Spearman $R$ & $t(N-2)$ & Value of $p$ \\
Left anterior superior iliac spine and left foot loading & 0.854962 & 16.3174 & $1.0783 \mathrm{E}-29$ \\
Left anterior superior iliac spine and right foot loading & -0.854962 & -16.3174 & $1.0783 \mathrm{E}-29$ \\
Right anterior superior iliac spine and left foot loading & -0.854962 & -16.3174 & $1.0783 \mathrm{E}-29$ \\
Right anterior superior iliac spine and right foot loading & 0.854962 & 16.3174 & $1.0783 \mathrm{E}-29$ \\
Left posterior superior iliac spine and left foot loading & 0.854962 & 16.3174 & $1.0783 \mathrm{E}-29$ \\
Left posterior superior iliac spine and right foot loading & -0.854962 & -16.3174 & $1.0783 \mathrm{E}-29$ \\
Right posterior superior iliac spine and left foot loading & -0.854962 & -16.3174 & $1.0783 \mathrm{E}-29$ \\
Right posterior superior iliac spine and right foot loading & 0.854962 & 16.3174 & $1.0783 \mathrm{E}-29$ \\
\hline
\end{tabular}

Table 2. The relationships between the pelvis and the arch of the feet

\begin{tabular}{|lccc|}
\hline Variables & Spearman $R$ & $t(N-2)$ & Value of $p$ \\
Left anterior superior iliac spine and left foot arch high & -0.225924 & 2.29590 & 0.023 \\
Left anterior superior iliac spine and right foot arch high & 0.198150 & 2.00127 & 0.048 \\
Right anterior superior iliac spine and left foot arch high & 0.225924 & 2.29590 & 0.023 \\
Right anterior superior iliac spine and right foot arch high & -0.198150 & 2.00127 & 0.048 \\
Left posterior superior iliac spine and left foot arch high & -0.225924 & 2.29590 & 0.023 \\
Left posterior superior iliac spine and right foot arch high & 0.198150 & 2.00127 & 0.048 \\
Right posterior superior iliac spine and left foot arch high & 0.225924 & 2.29590 & 0.023 \\
Right posterior superior iliac spine and right foot arch high & -0.198150 & 2.00127 & 0.048 \\
\hline
\end{tabular}

Only every sixth female and every third male managed to symmetrically distribute their body weight over their lower extremities in the habitual standing position. A half of the male participants and more than a half of the female participants bore their weight on the left foot. A symmetrical position of the pelvis was observed only in slightly more than a half of the participants of both genders. The left iliac spines were more frequently elevated in the case of an oblique position of the pelvis, both in females and in males. Lack of good body posture at a proper position of the pelvis was more frequent in females. More than two thirds of the participants had a proper arch of the right foot. In the case of the left one, its arch was more frequently lowered and had proper values in approximately $64 \%$ of participants. A number of significant dependencies were discovered between the variables under analysis. The correlation between the position of the pelvis in the frontal plane and the static lower extremity weight bearing was one of the most important ones. An elevated position of the left side of the pelvis occurred along with the excessive body weight bearing on the left foot and its lowered arch.
Table 3. The relation between the load setting of the lower limbs and the arch of the feet

\begin{tabular}{|lcc|}
\hline Variables & $r(X, Y)$ & $\begin{array}{c}\text { Value } \\
\text { of } p\end{array}$ \\
$\begin{array}{l}\text { Left foot loading and left foot } \\
\text { arch high }\end{array}$ & -0.305 & 0.002 \\
$\begin{array}{l}\text { Left foot loading and right foot } \\
\text { arch high }\end{array}$ & 0.146 & 0.146 \\
$\begin{array}{l}\text { Right foot loading and left foot } \\
\text { arch high }\end{array}$ & 0.305 & 0.002 \\
$\begin{array}{l}\text { Right foot loading and right foot } \\
\text { arch high }\end{array}$ & -0.146 & 0.146 \\
\hline
\end{tabular}

It was hard to say unambiguously that the students adopted bad body postures. However, quite frequently it did not match a basic criterion for good posture, i.e. symmetrical position of given bone structures towards the vertical axis. Undoubtedly, those observations could be explained by morphological and functional asymmetry connected with environmental influences, everyday activities and lateralization. However, a symmetric position of the trunk seemed 
to be exceptionally important for maintaining good posture in static and dynamic situations, in conditions in which keeping balance was harder, and while walking and performing precise movements with the upper extremity [10]. Habitual asymmetric trunk setting in children leads to the development of scoliosis [11], and in the elderly provokes pain [12].

Interesting observations on the position of the pelvis were made by Graf et al. [13]. Their research group consisted of several hundred girls aged 9 to 16 , out of which 200 were diagnosed with scoliosis, and 192 had proper body posture. Asymmetric position of iliac spines was discovered in $60 \%$ of the female participants with scoliosis and in $30 \%$ of healthy participants. Two times more frequent incidence of the oblique pelvic position in the female participants with lateral curvature of the spine suggested that the examination of the spine for scoliosis should also focus on the pelvic girdle [14]. The greater percentage of participants (almost 50\%) with the asymmetric position of the pelvis in the authors' own survey may have resulted from training in sports disciplines connected with asymmetric work of muscles by some of them.

The dependency found between an elevated position of iliac spines and greater weight bearing on the lower extremity on the same side of the body was similar to the findings of Stępień et al. [15]. In her gait analysis in children and adolescents with scoliosis, Stepien noted significant correlations between the lower extremity weight bearing in separate phases of the gait and the size and location of the lateral curvature of the spine. An elevated position of the pelvis functionally lengthened the extremity and increased its bearing weight.

Long-lasting weight bearing of the foot, due to overweight, may cause the lowering of its arch. The results of our survey proved the above hypothesis. Smaller Clark's angular values were characteristic of the foot which supports more weight. Lack of body balance, while maintaining good posture and in motion, overloads not only the foot but also the knee and hip joints [6]. However, it is the foot - despite its delicate structure - which suffers from the greatest weight bearing since it supports the heaviest weight [16]. That is why it seems to be justified to control the arch and positioning of the feet in children and adults with improper body posture [17, 18]. The foot, due to its structure, is adapted to sustain great loads; however, long-lasting and excessive weight bearing (in the case of overweight or working in a standing position) may lead to so-called functional flat feet, because of decreased efficiency of the muscles and the capsular ligament apparatus [19]. The incidence of a lowered foot arch in overweight children was confirmed many times, suggesting that it might be the beginning of discomfort which develops with age and weight gain [20].
One may wonder, taking into account the results obtained, whether the abnormalities discovered in young, healthy and physically active people will become a cause of greater dysfunctions and pain complaints in the future. According to statistics, as many as $80 \%$ of adults at least once in their lifetime have experienced lumbar pain of the spine, whose position and function were strictly connected with the position of the pelvis [21]. Increased weight bearing on one of the extremities may, in turn, contribute to the development of degenerative changes in the hip and knee joints. That is why one should introduce a prophylaxis programme for healthy people, which would include learning how to analyse and control the body at rest and in motion.

\section{Conclusions}

Asymmetric position of the pelvis and asymmetric body weight distribution over lower extremities are common also in young, healthy people who regularly undertake physical activities. There were discovered significant dependencies between the position of the pelvis in the frontal plane, static weight bearing and the longitudinal arch of the foot. One could observe a tendency towards a greater weight bearing on the lower extremity and a lower arch of the foot on the side of elevated iliac spines.

\section{References}

1. Barczyk K, Skolimowski T, Hawryluk A. Kształtowanie się asymetrii tułowia u dzieci w młodszym wieku szkolnym. Fizjoter Pol 2004; 3: 203-208.

2. Winter DA. Human balance and posture control during standing and walking. Gait Posture 1995; 3: 193-214.

3. Day JW, Smidt GL, Lehmann T. Effect of pelvic tilt on standing posture. Phys Ther 1984; 64: 510-516.

4. Kantor E, Poupard L, Le Bozec S, Bouisset S. Does body stability depend on postural chain mobility or stability area? Neurosci Lett 2001; 308: 128-132.

5. Wojtanowski W. Terapia manualna w korekcji wad postawy. PWSZ, Tarnów 2008.

6. Demczuk E, Anwajler J, Wojna D. Zrównoważenie ciała w płaszczyźnie czołowej a cechy morfologiczne stóp u dzieci w wieku 7-8 lat. Fizjoterapia 1993; 1: 33.

7. Kasperczyk T. Wady postawy ciała - diagnostyka i leczenie. Kasper, Kraków 2004.

8. Al-Eisa E, Egan D, Deluzio K, Wassersug R. Effects of pelvic asymmetry and low back pain on trunk kinematics during sitting: a comparison with standing. Spine 2006; 31 : 135-143.

9. Bibrowicz K, Skolimowski T. Występowanie zaburzeń symetrii postawy w płaszczyźnie czołowej u dzieci od 6 do 9 roku życia. Fizjoterapia 1995; 3: 26-29.

10. Horst R. Motorisches Strategietraining und PNF. Georg Thieme Verlag, Stuttgart 2005.

11. Nissinen M, Heliövaara M, Seitsamo J, Poussa M. Trunk asymmetry, posture, growth, and risk of scoliosis: a threeyear follow-up of Finnish prepubertal school children. Spine 1993; 18: 8-13. 
12. Al-Eisa E, Egan D, Deluzio K, Wassersug R. Effects of pelvic skeletal asymmetry on trunk movement: three-dimensional analysis in healthy individuals versus patients with mechanical low back pain. Spine 2006; 31: 71-79.

13. Graf K, Bronowski A, Napiórkowska M, et al. Ustawienie miednicy u dziewcząt zdrowych i z bocznym skrzywieniem kręgosłupa. Fizjoter Pol 2008; 8: 371-377.

14. Walaszek R, Kasperczyk T, Czapla D. Ocena funkcjonalna stawów obręczy biodrowej u dzieci ze skoliozami i zdrowych. Wych Fiz Zdrow 2006; 3: 12-17.

15. Stępień A, Seyfried A, Krawczyk M, et al. Wpływ deformacji kręgosłupa na sposób obciążania stóp w czasie chodu u osób ze skoliozą idiopatyczną. Post Rehab 2007; 2: $13-20$

16. Zieliński JR, Ilnicka L, Pacelt B, et al. Próba morfo-funkcjonalnej oceny stopy człowieka. Wych Fiz Sport 1994; 4: 83-92.

17. Evans AM. The flat-footed child-to treat or not to treat what is the clinician to do? J Am Med Assoc 2008; 98: 386-393.

18. Menz HB, Morris ME, Lord SR. Foot and ankle characteristics associated with impaired balance and functional ability in older people. J Geront Series A 2005; 60: 1546-1552.

19. Gołębiewska J, Pacelt B, Zieliński JR. Wpływ obciążeń statycznych na wybrane parametry budowy stopy. Wych Fiz Sport 2007; 51: 287-291.

20. Riddiford-Harland DL, Steele JR, Sturlien LH. Does obesity influence foot structure in prepubescent children. Int J Obes 2000; 24: 541-544.

21. Kwolek A, Korb D, Majka M. Rehabilitacja w zespołach bólowych dolnego odcinka kręgosłupa - zasady postępowania. Post Rehab 2004; 14: 27-31.

\section{Address for correspondence:}

Agnieszka Jankowicz-Szymańska Institute of Health

State Higher Vocational School

ul. A. Mickiewicza 8, 33-100 Tarnów, Poland

Phone: +48504 238962

E-mail: jankowiczszymanska@gmail.com 